………………....

Congenital Endocrinopathies

New Insights into Endocrine Diseases and Diabetes 


\section{Endocrine Development}

Vol. 11

Series Editor

Martin O. Savage London 


\title{
Congenital Endocrinopathies
}

\section{New Insights into Endocrine Diseases and Diabetes}

\author{
Volume Editors \\ Renata Lorini Genova \\ Mohamad Maghnie Genova \\ Giuseppe D'Annunzio Genova \\ Sandro Loche Cagliari \\ Martin O. Savage London
}

24 figures and 12 tables, 2007 
Renata Lorini, MD

Mohamad Maghnie, MD, PhD

Giuseppe D'Annunzio, MD

Department of Paediatrics

IRCCS, Giannina Gaslini

University of Genova

Genova, Italy

\section{Sandro Loche, MD}

Service of Paediatric Endocrinology

Regional Hospital for Microcytaemia

Cagliari, Italy
Martin O. Savage, MD

Paediatric Endocrinology Section

Department of Endocrinology

St Bartholomew's Hospital

West Smithfield, London, UK

Library of Congress Cataloging-in-Publication Data

Congenital endocrinopathies : new insights into endocrine diseases and

diabetes / volume editors, Renata Lorini ... [et al.].

p. ; cm. - (Endocrine development, ISSN 1421-7082; v. 11)

Includes bibliographical references and indexes.

ISBN 978-3-8055-8347-3 (hard cover : alk. paper)

1. Endocrine genetics-Congresses. 2. Endocrine glands-Diseases-Genetic aspects-Congresses. 3. Diabetes-Genetic aspects-Congresses. I. Lorini,

Renata. II. Series.

[DNLM: 1. Endocrine System Diseases-congenital-Congresses. 2. Child.

3. Diabetes Mellitus, Type 1-congenital-Congresses. 4. Growth

Hormone-metabolism-Congresses. 5. Infant. W1 EN3635 v.11 2007 / WS 330

C749 2007]

QP187.5.C66 2007

616.4'042-dc22

2007033860

Bibliographic Indices. This publication is listed in bibliographic services, including Current Contents ${ }^{\mathbb{R}}$ and Index Medicus.

Disclaimer. The statements, options and data contained in this publication are solely those of the individual authors and contributors and not of the publisher and the editor(s). The appearance of advertisements in the book is not a warranty, endorsement, or approval of the products or services advertised or of their effectiveness, quality or safety. The publisher and the editor(s) disclaim responsibility for any injury to persons or property resulting from any ideas, methods, instructions or products referred to in the content or advertisements.

Drug Dosage. The authors and the publisher have exerted every effort to ensure that drug selection and dosage set forth in this text are in accord with current recommendations and practice at the time of publication. However, in view of ongoing research, changes in government regulations, and the constant flow of information relating to drug therapy and drug reactions, the reader is urged to check the package insert for each drug for any change in indications and dosage and for added warnings and precautions. This is particularly important when the recommended agent is a new and/or infrequently employed drug.

All rights reserved. No part of this publication may be translated into other languages, reproduced or utilized in any form or by any means electronic or mechanical, including photocopying, recording, microcopying, or by any information storage and retrieval system, without permission in writing from the publisher.

(C) Copyright 2007 by S. Karger AG, P.O. Box, CH-4009 Basel (Switzerland)

www.karger.com

Printed in Switzerland on acid-free and non-aging paper (ISO 9706) by Reinhardt Druck, Basel

ISSN 1421-7082

ISBN 978-3-8055-8347-3 


\section{Contents}

VII Foreword

Savage, M.O. (London)

VIII Preface

Lorini, R.; Maghnie, M. (Genova)

1 Genomic Approaches in Genetic Research for Endocrine Diseases Ravazzolo, R. (Genova)

6 Genetic Defects of the Growth-Hormone-IGF Axis Associated with Growth Hormone Insensitivity

Woods, K. (Portland, Oreg.)

16 Late Effects of Disturbed IGF Signaling in Congenital Diseases Intrauterine and Postnatal Growth Retardation

Cianfarani, S.; Geremia, C.; Puglianiello, A.; Maiorana, A.; Germani, D. (Rome)

28 Growth Hormone Receptor Polymorphisms Controversies and Outcome of Growth Hormone Treatment Buzi, F.; Mella, P.; Pilotta, A.; Prandi, E.; Lanfranchi, F.; Carapella, T. (Brescia)

36 Genetic Disorders Involving Adrenal Development Lin, L.; Ferraz-de-Souza, B.; Achermann, J.C. (London)

47 Early Management and Gender Assignment in Disorders of Sexual Differentiation

Hughes, I.A. (Cambridge) 
58 Prenatal and Early Postnatal Treatment of Congenital Adrenal Hyperplasia

Ghizzoni, L.; Cesari, S.; Cremonini, G.; Melandri, L. (Parma)

\section{Neonatal Diabetes}

The Role of KCNJ11 (Kir6.2)

Tammaro, P. (Oxford)

83 Diagnosis of Neonatal and Infancy-Onset Diabetes

Barbetti, F. (Rome)

94 Management of Neonatal and Infancy-Onset Diabetes Mellitus

Søvik, O. (Bergen); Tansek, M.Z. (Ljubljana); Sagen, J.V.; Njølstad, P.R. (Bergen)

106 Insights in Congenital Hyperinsulinism

Hussain, K. (London)

122 A Clinical Approach to Severe Insulin Resistance

Savage, D.B.; Semple, R.K.; Chatterjee, V.K.K. (Cambridge); Wales, J.K.H.; Ross, R.J.M. (Sheffield); O'Rahilly, S. (Cambridge)

133 Inherited Endocrine Diseases Involving G Proteins and G Protein-Coupled Receptors

Spiegel, A.M. (Bronx, N.Y.)

\section{Stem Cells}

From Animal Research to Clinical Applications

Redi, C.A.; Monti, M.; Merico, V.; Neri, T.; Zanoni, M. (Pavia);

Zuccotti, M. (Parma); Garagna, S. (Pavia)

\section{Author Index}

\section{Subject Index}

This book has been printed with financial support from Pfizer Italia. 


\section{Foreword}

This volume reports the proceedings of an outstanding symposium, held in Genoa in January 2007, organised by Professor Renata Lorini and Professor Mohamad Maghnie, on the very imaginative subject of congenital endocrinopathies. This subject is broad by definition and the resulting volume is consequently interesting and informative and directly relevant to the care of the patient.

The volume contains reviews of normal and abnormal hypothalamicpituitary development affecting growth hormone $(\mathrm{GH})$ secretion and defects of the GH-IGF-I axis influencing GH and IGF-I action. Abnormalities of the pituitary-gonadal axis affecting normal puberty are covered together with defects of steroidogenesis involving both adrenal and gonadal development. The effect of glucocorticoid hormone programming in early life and defects of $G$ proteins and their receptors are also described. Key chapters are included on neonatal diabetes, congenital insulin resistance syndromes and the pathogenesis and management of persisting hyperinsulism of infancy. Finally, the application of stem cell research from animal studies to human diagnosis and therapy has been reviewed.

Overall this is an excellent volume. It provides information directly useful to the clinician and stimulates thought and future research opportunities with cutting-edge scientific results in the broad and very important field of congenital endocrinopathies.

Martin O. Savage, London 


\section{Preface}

In recent years, tremendous progress has been made in the field of genetics and congenital diseases both in endocrinology and in diabetology. The opportunity to provide an exceptional updated and prospective view of this field was given by the meeting on 'Congenital endocrinopathies: New insights into endocrine diseases and diabetes' held in Genoa, Italy, on January 18-19, 2007.

The scientific programme of the meeting was designed to focus on the most recent breakthrough advances relevant to endocrinology and diabetes. The impressive advances in gene technology have greatly improved our diagnostic and therapeutic skills as well as our understanding of the pathogenesis of paediatric endocrine diseases and diabetes.

This book provides an elucidation of the molecular aspects of various endocrine diseases but of course cannot be exhaustive in covering all the aspects of this complex field. Renowned and dedicated experts have covered the current evidence and future directions on these topics, and we believe that their contributions will ensure the exchange of valuable new information and ideas. We are confident that a synthesis of modern concepts of basic and clinical science within the broad field of molecular endocrinology and diabetology is represented here, and will provide a state-of-the-art book that is of value to physicians, non-clinical scientists and students from many disciplines. 